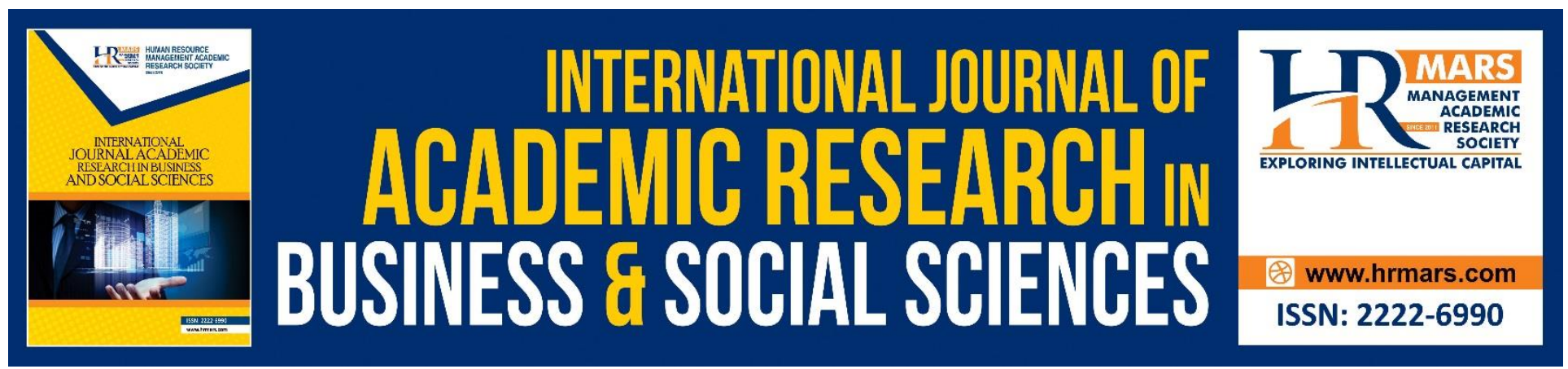

\title{
The Importance of Early Intervention Programs on the Development of Special Needs Individual
}

\author{
Borhannudin Abdullah, Wan Nomi Wan Omar
}

To Link this Article: http://dx.doi.org/10.6007/IJARBSS/v8-i12/5049

DOI: $10.6007 /$ IJARBSS/v8-i12/5049

Received: 17 Nov 2018, Revised: 24 Dec 2018, Accepted: 27 Dec 2018

Published Online: 28 Dec 2018

In-Text Citation: (Abdullah \& Omar, 2018)

To Cite this Article: Abdullah, B., \& Omar, W. N. W. (2018). The Importance of Early Intervention Programs on the Development of Special Needs Individual. International Journal of Academic Research in Business and Social Sciences, 8(12), 510-516.

Copyright: (C) 2018 The Author(s)

Published by Human Resource Management Academic Research Society (www.hrmars.com)

This article is published under the Creative Commons Attribution (CC BY 4.0) license. Anyone may reproduce, distribute, translate and create derivative works of this article (for both commercial and non-commercial purposes), subject to full attribution to the original publication and authors. The full terms of this license may be seen at: $\underline{\text { http://creativecommons.org/licences/by/4.0/legalcode }}$

Vol. 8, No. 12, 2018, Pg. 510 - 516

Full Terms \& Conditions of access and use can be found at http://hrmars.com/index.php/pages/detail/publication-ethics 


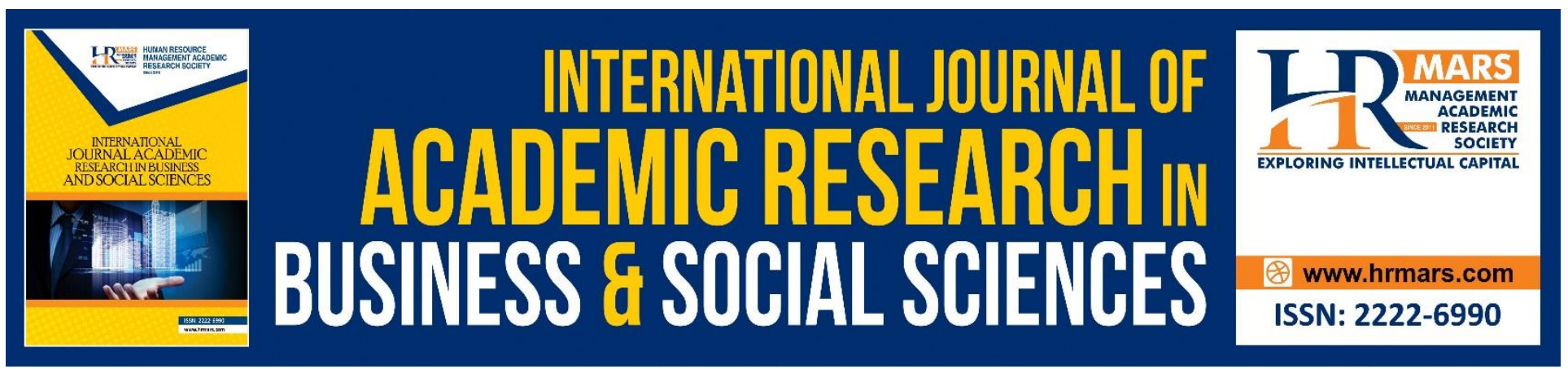

\title{
The Importance of Early Intervention Programs on the Development of Special Needs Individual
}

\author{
Borhannudin Abdullah ${ }^{1}$, Wan Nomi Wan Omar ${ }^{2}$ \\ ${ }^{1}$ Faculty of Educational Studies, Universiti Putra Malaysia, 43400 UPM Serdang, Selangor Darul \\ Ehsan, Malaysia \\ ${ }^{2}$ Special Education Division, Putrajaya
}

\begin{abstract}
The purpose of this study is to improve special needs children with problem in motor skills through intervention programs. Special needs children who have motor issues will have developmental delay problem. The study took a closer look into these special needs children with developmental delay problem. These children were carefully observed and monitored to record their responses and progresses throughout the intervention processes. These children would go through a screening test using Denver II instrument to identify the baseline of their developmental domain potential and issues before they started the intervention programs. The observation lasted for 3 months. The progresses of the students were charted in the form of bar chart. The result shows that the intervention programs have improved the performance of the children and their overall developmental domain. There are significant differences between before and after the intervention. Thus, the interventions are able to increase the children gross motor skills. The study also identifies the support and involvement of the parents as important factor in ensuring the early intervention to be implemented successfully.
\end{abstract}

Keywords: Child Development, Intervention, Children With Special Needs, Parents

\section{Introduction}

Early intervention program aims to assist parents in providing early screening and intervention to minimize the learning barriers caused by their disabilities. According to Hallahan Kaufman (2003), most educators and professionals of social sciences believe that the earliest the children receive intervention, the better chances for them to perform academically. Their readiness to study and pay better attention to the classroom lessons are improved tremendously. An intensive early intervention programs will lessen the barriers they face due to their disabilities so that they can learn better in schools. Early intervention is defined as a systematic and well structured approach in strengthening the developmental domain of babies and children who have developmental delay problems (Fatimah Bivi, 2002). Early intervention services consist of various health treatment, habilitation, guidance and 
professional advices on dealing with the impacts of disabilities as soon as it is identified (Kail, 2001). The services are provided as early as possible to help children and parents deal with the disabilities issues. The services help to ensure that the children language, social, emotion and psychomotor development are not further hampered as they grow older.

Special needs children must be screened and diagnosed at the early stage to identify the suitable and relevant education pathways that can develop their individual potentials effectively. Each children should receive a well structured and continuous intervention services started with early intervention from birth until preschool stages. Early intervention programs required collaboration from multidisciplinary professionals (Zarin, Safani \& Soon, 2004). Early intervention services assist in strengthening the special needs children developmental domain particularly in communication skills. There are children who benefit from an intervention activities that enhance their nonverbal communication skills rather that verbal skills like normal children. Special needs children with speech problems due to physical and cognitive issues will benefit greatly from speech intervention programs. Various alternative communication modes for example sign language and through the usage of augmentative alternative communication (AAC) assistive devices could be adapted in the classroom. There autistic children who require medical attention to help them cope with the issues of low attention span and hyperactivity disorder. A special presciption like vitamin B6 can help those children to increase their awarenes and attention span.

An effective early intervention programs require strong involvement of parents, teachers and support service professionals such as occupational therapist, speech pathologist and others. All these people play important role in providing motivation and encouragement naturally in the children daily lives. They can talk to the children about things that they like and enjoy doing and together they can plan the best way to carry out the intervention. The intervention activities should be embedded and done throughout their daily living activities. It can happen during classroom activities or during family outing like in a fast food restaurant or other various places. The children should be supported and encouraged to use correct manner and language to communicate with people. As for the autistic children, early intervention activities help them to lessen their behavior management problems and emotional issues. All relevant parties need to work together to provide effective intervention services. In America, intervention programs are carried out through cooperation and partnership between various agencies such as technical support, school nurse, parents, counselors, nutritionist, therapist and others.

Early intervention activities provide opportunities for special needs children to learn and master skills in various areas including social skills, self-care skills, communication skills and behavior management skills. In Malaysia, early intervention services are provided for autistic children at the preschool levels to get them ready for formal education at the primary level. Self-care skills and behavior management skills are prioritized as the foundation to help them learn other subjects such as Malay Language, Religion, Morale and Mathematic. Teachers must have a vast knowledge to carry out effective teaching and learning processes. Teachers with good knowledge of behavior management 
techniques will able to attract and motivate the children to learn and manage the children behavior so that they will pay better attention to the lesson.

Early intervention services are provided to parents as well as the children themselves to enhance their developmental domain in 5 areas: physical development, cognitive, communication, social and emotion (Sandler, Brazdziunas, Cooley \& De Pijem 2001). Among the intervention services needed are occupational therapist, speech pathologist, physiotherapist, audiologist, and also support and guidance to parents (Addison 2003). In America, the early intervention programs are available for children who have developmental delay from birth (o years old) to 6 years old (U.S. Department of Education, 2004). In order to assist these special children, Malaysia has also made available the early intervention program from birth up to preschool with the cooperation of Ministry of Health and various non-governmental organization (NGO). Ministry of Education, Malaysia has provided access to special education for 6 categories of special needs children: the hearing impaired, the vision impaired, learning disabilities, speech problem, physical handicapped, and multiple disabilities. Early intervention programs can help all these children to minimize the impact of their disabilities and prevent it from deteriorate and becoming more serious (Majnemer 1998). It maximizes the children potential to help them be independent and able to contribute to the society.

Addison (2003) concluded that among the positive influences of early intervention activities to the special needs children are the improvement on the level of children developmental domain, prevention of further issues, decreasing the pressure on the family members and increasing the children readiness to learn. Guralnick (1997) described early intervention services as a system designed to support family so parents can interact with family members to make them understand the situation and together assist the special needs children.

There are studies that show intervention given before the children reach 48 months old will yield higher performances compared to the result of intervention given after the children are 48 months old (Harris \& Weiss 1998, Sheinkopf \& Siegel 1998). Similarly, Haris and Handleman (2000) emphasized that early intervention given before 3 years old would provide more effective supports compared to the result of intervention given to children after they have reached 5 years old. All these findings have proved the importance of early intervention for autistic children to grow like the normal children.

\section{Methodology}

This study uses qualitative approach with a case study or more of clinical nature. One special needs child with a split brain issue was selected as a sample. The child was 20 months old (1 year and 8 months). The child has developmental delay or late development. The child parents have given their consent for the researcher to let their child to be involved in the study. The researcher has managed to collaborate with the Community Based Rehabilitation (CBR) center, Special Education Support Services Center (3PK) and local hospital to organize a structured early intervention program for this child. The child performances and progresses were monitored and recorded. The performances were assessed using the Denver II Instrument. The interventions given were based on the Series of Six 
INTERNATIONAL JOURNAL OF ACADEMIC RESEARCH IN BUSINESS AND SOCIAL SCIENCES

Vol. 8, No. 12, Dec, 2018, E-ISSN: 2222-6990 C 2018 HRMARS

Manuals on the Management of Children with Disabilities published by the Ministry of Health, Malaysia.

The therapist used pretest as a baseline to begin the intervention programs. Each of the performances would be recorded and reported in the Individualized Family Service Plan (IFSP) which has been established for this study. This IFSP report will help the relevant parties to take plan and arrange feedback to assist the child.

\section{Findings}

\section{Levels of Gross Motor, Fine Motor, Social and Language Development}

In the period of 3 months, several development recorded have shown a positive improvement. Diagram 1 shows the performance levels in the areas of social, language, gross motor and fine motor.

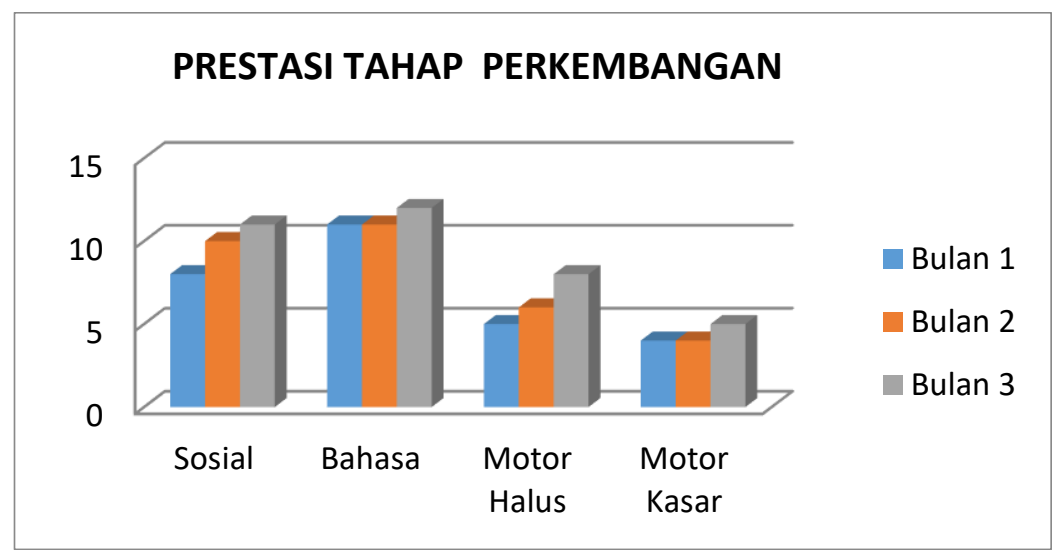

Diagram 1: The Child's Levels of Development

A well structured intervention programs with comprehensive schedule and support as well as commitment of all involved in the multidisciplinary team have succeed in improving the child performance in a positive way. Even though the performances are yet to be in par with the normal child, it is in line with the development based on the child choronological age. Any new activities were planned and implemented based on the feedback from the IFSP recorded document. Among the developmental domain of the child, the gross motor domain has shown improvement rather late at the end of the programs. The developmental delay was recorded as 1 year and 3 months from the chronological age. Meanwhile, for the social domain, the delay was 9 months, the delay on language was 8 months and the delay on fine motor was 12 months from the chronological age.

\section{Discussion}

The early intervention programs have achieved its aim with the evidences of improvement on developmental domains of the special needs child. Nevertheless, the performances depend on the collaborative efforts of all relevant individuals such as parents, professional therapist and hospital. The programs were successful due to proper planning and detail preparation of all individuals involved (Weishaar \& Borsa, 2001). 
The available assessment instrument has made it easy for the therapist to plan the activities according the individual needs based on the strength of the special needs children. The instrument has managed to assess the development levels of the children and was able to explain to parents their children performances. This has helped teachers to convince parents on the benefit of early intervention programs on their children. Continuous supports from parents are vital to the success of early intervention programs.

The intervention programs that are based on the intervention series published by the Ministry of Health can be done by many others by working in partnership with various professional individuals. The programs can be done at home not just at hospital or specific centers. The awareness, cooperation and commitment of parents and family members play important roles in ensuring effective intervention.

\section{Summary and Suggestions}

A well plan, structured and continuous intervention programs with strong supports from all relevant individuals will definitely help to improve the children developmental domain. Beginning with early interventions which will assist in ensuring the readiness of the children to learn in schools, the interventions will then continued throughout the schooling years. The IFSP will provide the well plan and structure early intervention programs and then it will be continued through the Individualized Education Plan (IEP) during the primary and secondary level of education. Regular discussions with parents and the multidisciplinary team need to be carried out to improve the intervention programs. Teachers and parents should communicate and support each other to assist the students to grow and develop with their full potential.

\section{References}

Cohen, J. A. (1960). Coefficient of agreement for nominal scales. Educational and Psychological Measurement, 20, 37-46.

Cook, B. G., \& Schirmer, B. R. (2003). What is special about special education? Journal of Special Education, 3, 200-205.

Ernie Suliana Md. Shariff (2008). Prestasi Kemahiran Motor Halus dan Motor Kasar KanakKanak Masalah Pembelajaran Menggunakan Instrumen Movement Assessment Battery For Children (MABC). Universiti Teknologi Malaysia dilayari pada 25 November 2013

Frankenburg, W.K., Dodds, J.B., \& Archer, P. (1990). Denver II technical manual. Denver, CO: Denver Developmental Materials.

Gallahue, D. L., \& Ozmun, J. C. (2012). Understanding motor development: Infants, children, adolescents, adults. New York:McGraw-Hill.

Heufner, D. S. (2000). The risks and opportunities of the IEP requirements under IDEA '97. Journal of Special Education, 33, 195-204.

Kail , R., \& Hal I , L. K. (2001). Distinguishing Short-term Memory from Working Memory. Memory \& Cognition 2001, 29 (1), 1-9

Kalverboer AF. (2002). Development of Early Motor Skills and Language in Children at Risk for Familial Dyslexia. Development Medicine \& Child Neurology, 44: 761-769

Lee-Tarver, A. (2006). Are individualized education plans a good thing? A survey of teachers' 
INTERNATIONAL JOURNAL OF ACADEMIC RESEARCH IN BUSINESS AND SOCIAL SCIENCES

Vol. 8, No. 12, Dec, 2018, E-ISSN: 2222-6990 C 2018 HRMARS

perceptions of the utility of IEPs in regular education settings. Journal of Instructional Psychology,33, 263-272

Lerner. S.J., \& Loewenstein. G. (2003). The Role of Affect Decision Making. Capter 31, 619-641

Stanton-Chapman, T. L., Kaiser, A. P., Vijay, P., \& Chapman, C. (2008). Teaching social

interaction skills to children at-risk for emotional and behavioral disorders. Journal of Early Intervention, 30, 188-212.

Ulrich, D.A. (2005). Test of Gross Motor Development (2nd ed). Austin, TX: Pro-Ed Publish.

Weishaar, M. K. (2001). The regular educator's role in the individual education plan process.

The Clearing House, 75, 96-98.

Woods, J., \& Poulson, C. L. (2006). The use of scripts to increase the verbal initiations of children with developmental disabilities to typically developing peers. Education \& Treatment of Children, 29, 437-457. 